\title{
Het experiment decentrale selectie voor de artsopleiding: geslaagd of mislukt?
}

Met het symposium 'Selectie: taboe doorbroken? De toekomst van decentrale toelating in het hoger onderwijs' presenteerde op 19 februari 2003 de Begeleidingscommissie Decentrale Toelating - in de wandelgangen de Commissie Sorgdrager - haar eindrapport onder de titel 'De juiste student op de juiste plaats'. ${ }^{1}$ In een volgend nummer van dit tijdschrift zal een bijdrage van Sorgdrager hierover verschijnen.

De commissie concludeert dat niet over de hele linie het experiment geslaagd is. Wel is het draagvlak duidelijk toegenomen. De commissie beveelt een voortgaande toepassing aan. Namens de staatssecretaris nam de directeur hoger onderwijs van het Ministerie van Onderwijs, Cultuur en Wetenschappen, Roborgh, het rapport in ontvangst met de constatering dat er in Nederland angst heerst voor selectie en dat het 'gedegen onderzoek' in dit rapport zal naklinken in het eerstkomende Hoger onderwijs- en onderzoekplan.

Is het selectie-experiment voor de artsopleiding inderdaad geslaagd te noemen? Is daar evenwichtig over gerapporteerd en was er een verhelderende discussie op het symposium? Mijn oordeel is drie keer: nee, overigens met de kanttekening dat de medische opleidingen wel wat positiefs hebben overgehouden aan het selectieexperiment.

Wat is er sinds 2000 gebeurd? Van de acht medische faculteiten hebben er eerst twee (Leiden en Utrecht) en later vijf (ook de beide Amsterdamse opleidingen en Rotterdam) serieus meegedaan aan selectieexperimenten voor de instroom van eerstejaarsstudenten. Leiden en Utrecht zijn hier inmiddels weer mee opgehouden. Alleen Rotterdam breidt voor het komende jaar de selectie uit, om over enkele jaren een beter oordeel te kunnen vellen. De medische opleidingen stellen zich rationeel op: selecteren als daar wat mee te winnen valt, zowel voor de aankomende studenten als voor de afstuderende studenten; niet selecteren als dat niet het geval is. De winst is tot nu toe niet overtuigend aangetoond. Wel is duidelijk dat selectie grote inspanning kost, te schatten op meer dan $1 \mathrm{fte}$ per dertig ingevulde plaatsen.

Het is niet zo moeilijk te begrijpen waarom de selectie van vwo-scholieren niet goed is aangeslagen, ook al is dat zo niet terug te vinden in het evaluatierapport. De opleidingen wordt gevraagd te selecteren binnen de groep vwo-ers met minder hoge eindexamencijfers (de $8^{+}$-studenten komen zonder selectie of loting al binnen), geen gebruik te maken van cognitieve criteria (wel van onduidelijk omschreven 'motivatie en specifieke talenten') en criteria te vermijden die de studielast op het vwo vergroten. De ruimte om hierbinnen te selecteren is er eenvoudig niet, zeker niet evidence-based. Met uitzondering van eindexamencijfers die niet gebruikt mogen worden - bestaan er niet of nauwelijks bruikbare selectiecriteria die een betere studie- of beroepskwaliteit voorspellen, en de eisen die nu aan de opleidingen worden gesteld bij de toepassing van decentrale selectie zijn niet in redelijkheid waar te maken. ${ }^{2-6}$ Van de opleidingen kan moeilijk verwacht worden dat zij dit alles alleen doen om de scholier te plezieren. De opdracht aan de faculteiten is immers om goede artsen af te leveren. 
Er heerst, getuige de discussies tijdens het symposium van 19 februari, zelfs onder mensen die direct bij het onderwerp selectie betrokken zijn geweest, een hardnekkig onbegrip over wat het selectieprobleem nu eigenlijk is. De maatschappelijke commotie is uiteraard niet ontstaan omdat veel mensen vinden dat zij of anderen ten onrechte wel worden geselecteerd. Onvrede ontstaat als veel mensen vinden dat zij (of anderen) ten onrechte niet worden toegelaten. Iedereen die gemotiveerd is voor de opleiding, is bij afwijzing natuurlijk teleurgesteld; daar verandert niets aan als loting door selectie wordt vervangen. De oproep die uit de hele wetgeving klinkt -'geef de vwo-er meer mogelijkheden het lot in eigen hand te nemen!' - of de oproep van schooldecanen - 'faculteiten, geef nou eens helder aan wat jullie selectiecriteria zijn, dan zorgen wij wel dat onze scholieren met hun portfolio daaraan kunnen voldoen' - missen dan ook de kern. De commotie begon met verontwaardiging dat een vwo-er met alleen 10en werd uitgeloot. Dat is inmiddels door de 8+-regeling opgelost. Direct daarna heeft de commotie zich verplaatst naar een oproep om 'niet alleen op cijfers en cognitieve prestaties te selecteren'. Logisch, want van de bollebozen komt geen protest meer. Als we er ooit in zouden slagen motivatie als selectiecriterium te gebruiken (wat ik voor vrijwel onmogelijk houd), komt er vast weer een andere protestgroep bovendrijven. Herinnert $\mathrm{u}$ zich nog de slogan van De Tegenpartij van Van Kooten en De Bie? "Geen gezeik, iedereen rijk". Hier is het: geen loting meer, iedereen toelaten, desnoods via decentrale selectie! De Tegenpartij zou zeggen: Geen gelul, iedereen een bul!

Slechts de twee cabaretiers die de symposiumgangers als jagers in de pauze kwamen vermaken door onder het pu- bliek de zwakke dieren af te schieten, raakten enigszins het probleem: dat probleem is niet de centrale of decentrale toelating via loting of selectie, maar de centrale of decentrale afwijzing via loting of selectie. Immers, de aanleiding voor decentrale selectie onder vwo-scholieren is niet dat we nu te veel ongeschikten toelaten, maar dat er te veel geschikten zijn om binnen de numerus fixus toegelaten te kunnen worden. Onder hen is selectie met de huidige wetgeving niet echt goed mogelijk en daarom blijft een gewogen loting in deze groep vwo-ers, mijns inziens, nog steeds de best verdedigbare oplossing. ${ }^{7}$

Is er ook ander nieuws over selectie te melden? Jazeker. Voor de toelating voor 2003/2004 gaan drie artsopleidingen (Leiden, Utrecht en Groningen) wel selecteren voor de toelating van studenten voor een verkort, vierjarig, opleidingstraject. In deze beperkte groep, met een grote diversiteit aan voorkennis, is selectie wel echt zinvol. Er is mijns inziens bij de medische opleidingen dan ook in het geheel geen angst voor selectie en ook is er geen taboe doorbroken. Overal in de wereld wordt geselecteerd voor medische opleidingen en dat Nederland daar wat anders tegenaan kijkt, getuigt eerder van moed en rationaliteit dan van angst.

\section{Olle ten Cate}

\section{Literatuur}

1. De juiste student op de juiste plaats - eindrapportage van de Begeleidingscommissie Decentrale Toelating, OCE Facilities Service, januari 2003. http://www.minocw.nl/onderwijs/hogeronderwijs.html.

2. Ferguson E, James D, Madeley L. Factors associated with success in medical school: systematic review of the literature. BMJ 2002;324:952-7.

3. Salvatori P. Reliability and validity of admissions tools used to select students for the health professions. Advances in Health Sciences Education 2001;6(2):159-75 
4. Cohen-Schotanus J, Reinders JJ, Agsteribbe J, Meyboom-de Jong B. Tien jaar arts: een longitudinaal onderzoek naar de loopbaan vanaf het afstuderen. Ned Tijdschr Geneeskd 2002;146(51):2474-8.

5. Cate ThJ ten, Hendrix HL, Fockert Koefoed KJJ de, Rietveld W. Studieresultaten van toegelatenen binnen en buiten de loting. Tijdschrift voor Medisch Onderwijs 2002;21(3):253-8.

6. Cate ThJ ten, Klijnhout PJ. Intentie en uitvoeringspraktijk van decentrale selectie van studenten geneeskunde - een analyse over de criteria. Tijdschrift voor Medisch Onderwijs 2002;21(3):91-103.

7. Cate ThJ ten, Rossum HJM van, Vleuten CPM van der. Huidige lotingsysteem is het beste. NRC-handelsblad 12 april 1997. 